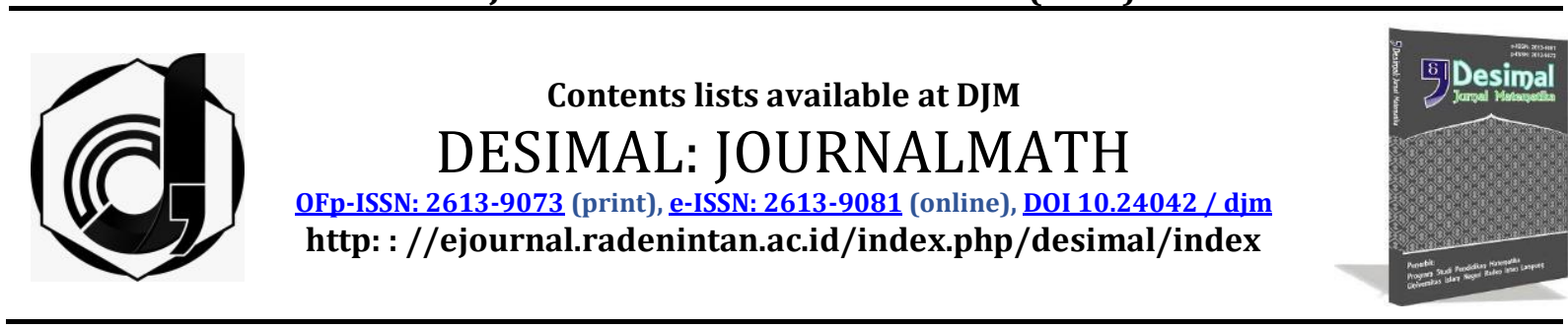

\title{
The Implementation of Student Worksheets (LKM) on Relations and Functions through Website-based guided-inquiry approach student worksheet
}

\author{
Netriwati*, Busmayaril \\ Unversitas Islam Negeri Raden Intan Lampung, Indonesia
}

\author{
ARTICLE INFO \\ Article History \\ Received: 10-11-2019 \\ Revised: 10-04-2020 \\ Accepted: 05-05-2020 \\ Published: 20-05-2020 \\ Keywords: \\ Student Worksheet (LKM); \\ Guided Inquiry. \\ * Correspondence: E-mail: \\ netriwati@radenintan.ac.id \\ Doi: \\ $\underline{10.24042 / \operatorname{djm} . v 3 i 2.5212}$
}

\begin{abstract}
Student Worksheet is a learning media that can be used as a guide for students and lecturers in the teaching and learning process. The developed product of this research is a website-based guidedinquiry approach student worksheet. The purpose of this study is to improve students' learning outcomes and motivation in learning mathematics. This research employed the pre-experimental method with one-group pretest-posttest design. The small-scale testing obtained an average score of 3.1 which is included in the interesting category. The large-scale testing obtained an average score of 3.26 which is included in the very interesting category. The website-based guided-inquiry approach student worksheet obtained an average score of 0.48 which is included in the medium category for its effectiveness. It can be concluded that the websitebased guided-inquiry approach student worksheet is feasible and very interesting to be used in increasing student motivation and learning outcomes for better learning in Basic Mathematics course.
\end{abstract}

\section{INTRODUCTION}

Student worksheet is a learning media that can be used by the students and lecturers to direct the teaching and learning process (Eli Rohaeti, et.ol 2009). Student worksheet is a learning media that can be used as guidelines and can help the students and lecturers in the learning process (Zulyadaini, 2017).

The lecturer of the Basic Mathematic course have not used the website-based guided-inquiry approach student worksheet. Therefore, designed LKM in accordance with the characteristics of teaching materials and student characteristics.

Guided-inquiry is a learning approach that includes activities based on scientific methods, such as observing, formulating relevant questions, planning investigations, reviewing what is already known, conducting experiments using tools to obtain data, analyzing and 
interpreting data, as well as making predictions and communicating the results (Sabmei, 2011). The approach guides and provides direction for students in carrying out activities even if the ability of students in each class is different, they can do the learning process (Yenny, 2014).

Mathematics learning has applied the inquiry approach but it is not yet based on a website. Lecturers should be able to design a learning that refers to the guidedinquiry approach. Through website-based guided-inquiry approach student worksheet, students will be helped to find mathematical concepts easily.

The rapid development of science and technology is a means to develop the reasoning power as well as logical, systematic, and critical thinking to facilitate students to learn independently. Website-based learning is a learning activity that utilizes websites that can be accessed through the internet and is one type of application of electronic learning (e-learning). Websites can be used in teaching and learning process as teaching material in the form of student worksheets. According to Richard and Tomlinson, ideal teaching materials and worksheets are devices that can provide information and learning experiences that are designed with good features (Wiwik, 2016).

Research conducted by Saidatun shows that the student worksheet based on guided-inquiry approach on Plant Physiology course has been effectively applied in learning (Saidatun, 2016). The same thing was also done by Annisa. Her finding is that physics learning media in the form of websites is appropriate to be used as learning media (Annisa, 2019).

Website-based learning is a learning process that utilizes information technology such as the internet. Websitebased learning or better known as webbased learning is one type of application of the electronic learning process (elearning) where the materials are delivered via the internet (Rusman, et al, 2012).

Based on some of the findings above, the researchers conducted research on the implementation of website-based guidedinquiry approach student worksheet with the hope that the designed product could be used to motivate and improve students' learning outcomes.

\section{METHOD}

This study employed the PreExperimental method with One-Group Pretest-Posttest Design (Sugiyono, 2012).

\section{Place and Time of Research}

This research was conducted at the Raden Intan Islamic State University of Lampung in the second semester.

\section{The Research Procedures}

The website-based guided-inquiry approach student worksheet was validated by material experts and media experts. The objective of the validation was to determine the validity of the developed product. The website-based guided-inquiry approach student worksheet was declared as valid and feasible. It was then tested on the teaching and learning process of Basic Mathematics Course. The testing was carried out through websites that have been notified previously. The students then filled-out the questionnaire. The product testing was conducted in 2 ways, namely smallscale testing and large-scale testing. The small-scale testing involved 10 students and the large-scale testing involved 24 students.

The Instruments of Data Collection

Theinstruments of this research were 1) expert validation instruments consisted of validation instruments for the material experts and media experts to determine whether an developed website- 
based guided-inquiry approach student worksheet has been designed well or not; 2) questionnaire for students to determine the attractiveness of the designed website-based guided-inquiry approach student worksheet; 3) product testing instruments consisted of pretest and posttest to demonstrate the effectiveness of the developed websitebased guided-inquiry approach student worksheet.

\section{Data analysis techniques}

$\mathrm{N}$-gain was used to analyze the data by calculating the difference between the pretest and posttest sores which then divided by the difference between the maximum score and the pretest score. To find the N-gain value, the formula used was:

$\mathrm{n}-$ gain $=\frac{(\text { posttest score }- \text { pretest score })}{(\text { maximum score }- \text { pretest score })}$

The effectiveness criteria of the developed website-based guided-inquiry approach student worksheet can be seen in Table 1.

Table 1. Effectiveness Criteria

\begin{tabular}{cc} 
Criteria & $\begin{array}{c}\text { Effectiveness } \\
\text { Level }\end{array}$ \\
$\mathrm{N}$-gain $\geq 0.7$ & High \\
$0.3<\mathrm{N}$-gain $<0.7$ & Medium \\
$\mathrm{N}$-gain $\leq 0.3$ & Low \\
\hline
\end{tabular}

The website-based guided-inquiry approach student worksheet have were declared as valid and feasible to be used in Basic Mathematics Course. After the website-based guided-inquiry approach student worksheet have been declared as valid and feasible, it was tested on students. The small-scale testing to 10 students obtained an average score of 3,1 which belonged to the attractive category. The large-scale testing to 24 students obtained an average score of 3.26 which belonged to the very attractive category. The results of the small-scale and largescale testing can be seen in Figure 1.

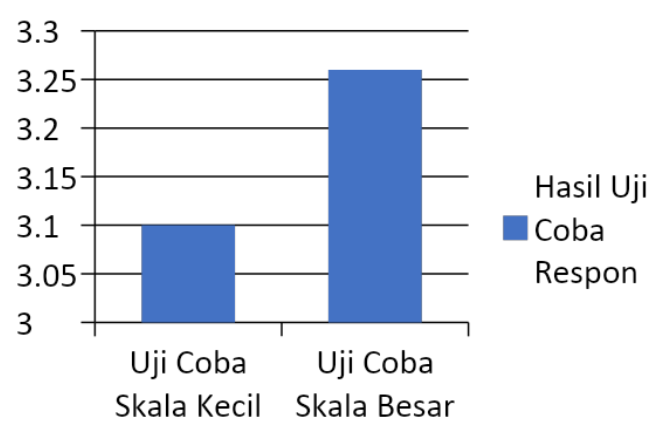

Figure 1. The Results of the Small-Sclae and Large-Scale Testings

After the testings have been carried out, the effectiveness of the website-based guided-inquiry approach student worksheet was investigated through pretest and posttest. The following is the data of the pretest and posttest

\section{RESULTS AND DISCUSSION}

Table 2. The Pretest and Postetst Data Calculation Results

\begin{tabular}{llllcc} 
Tests & $\mathrm{n}$ & Ideal Score & Maximum Score & $\begin{array}{c}\text { Minimum } \\
\text { Score }\end{array}$ & Average \\
& & & & 20 & 39.6875 \\
Pretest & 32 & 100 & 60 & 55 & 74.0625 \\
posttest & 32 & 100 & 85 & & \\
\hline
\end{tabular}

Table 2 displays that the average pretest and posttest scores have been increased by $11 \%$. Then, based on this result, the $\mathrm{N}$-gain value was calculated.
The N-gain calculation results can be seen in Table 3.

Table 3. The Recapitulation of N-gain Value 
Desimal, 3 (2), 2020 - 172

Netriwati, Busmayaril

\begin{tabular}{cccccc}
\hline Class & $\mathrm{n}$ & & & Values & \\
& & Ideal & Maximum & Minimum & Average of \\
& & Score & Score & Score & N-gain \\
Class B & 32 & 100 & 0.7 & 0.09090 & 0.48204 \\
Semester 1 & & & & & \\
\hline
\end{tabular}

Based on Table 3, it can be seen that the maximum score of the pretest and posttest results is 0.7 and the minimum score of the pretest and posttest is 0.09090 . The average $\mathrm{N}$-gain of the pretest and posttest is 0.48204 . based on the data, it can be seen that the $\mathrm{N}$-gain value obtained is 0.48 which is included in the medium category.

It can be seen that the website-based guided-inquiry approach student worksheet are feasible and interesting to be used in mathematics lectures to motivate and improve the learning outcomes.

This is in line with Jackson Pasini Mairing's research entitled "Development of Problem-Based Student Worksheets and Projects in the Data Analysis Course". The research found that the student worksheet was a sheet containing material that made students more active in the process of learning so that it influenced and motivated the students to learn the available material.

Besides the research conducted by Jackson, research conducted by Eko Prihandono on student worksheet based on Guided Inquiry to improve science process skills could improve students' Science Process Skills in the medium category (Eko, 2018).

Based on some previous research findings, the website-based guidedinquiry approach student worksheet can be effectively used in the learning process.

\section{CONCLUSIONS AND SUGGESTIONS}

The conclusions of this study are: (1) the developed website-based guidedinquiry approach student worksheet is included in the very interesting category; (2) the effectiveness of website-based guided-inquiry approach student worksheet is included in the medium category.

Further researchers are expected to; (1) include other materials according to the needs of students; (2) test the websitebased guided-inquiry approach student worksheet si that it can be used by different subjects.

\section{AKNOWLEDGMENT}

The researchers express their gratitude to UIN Raden Intan Lampung for funding this research. The funding of this research comes from the Institute of Research and Community Service of UIN Raden Intan Lampung in the fiscal year of 2019.

\section{REFERENCES}

Annisa Shabrina, Rahma Diani. (2019). Development of Physical Learning Media Based On Web Enhanced Course With Guided Inquuiry Model. Indonesian Journal of Science and Mathematics Education. 02 (1), 2.

Meidawati, Yenny. (2014). Pengaruh pendekatan pembelajaran inkuiri tebimbing terhadap peningkatan kemampuan pemecahan masalah matematis siswa SMP. Jurnal pendidikan dan keguruan, 1 (2), 4.

Ni'mah, Saidatun. (2016). Lembar Kerja Mahasiswa Berbasis Inkuiri Terbimbing Untuk Meningkatkan Keterampilan Proses Sains Mahasiswa. Lentera:Jurnal Ilmiah Kependidikan, 11 (2), 60.

Prihandono, Eko. (2018). LKM Berbasis Inkuiri Terbimbing Untuk Meningkatkan Proses Sains. Jurnal Pendidikan Fisika. 6 (2), 202-222.

Rohaeti, Eli, Endang Widjajanti, dan Regina Tutik Padmaningrum. (2009). Pengembangan lembar 
kerja siswa (LKS) mata pelajaran sains kimia untuk SMP. Jurnal Inovasi Pendidikan, 10 (1). 2.

Rusman Rusman, Deni Kurniawan dan Cepi Riyana. (2012). Pembelajaran Berbasis Teknologi Informasi dan Komunikasi, Jakarta : PT Raja Grafindo Persada.

Sugiyono. (2012). Metode Penelitian Kuantitatif, Kualitatif, dan R\&D. Bandung: Alfabeta.

Sukamsyah, Sabmei. (2011). Upaya Peningkatan Hasil Belajar Dengan Penerapan Metode Inkuiri Terbimbing Tipe A Pada Konsep Kalor Siswa Kelas VII SMP N 5 Seluma. Jurnal Exacta, 9 (1), 39.

Wiwik Sri Utami et al. (2016). The Effectiveness of Geography Student Worksheet to Develop Learning Experiences for High School Students. Journal of Education and Learning, 5 (3),, 2016.

Zulyadaini Zulyadaini. (2017). A Development of Students' Worksheet Based on Contextual Teaching and Learning. International Journal of Learning, Teaching and Educational Research, 16 (6), 1. 
Desimal, 3 (2), 2020 - 174

Netriwati, Busmayaril 